\title{
Shibusawa Eiichi, Dai Ichi Bank, and the Spirit of Japanese Capitalism, 1860-1930
}

\author{
John Sagers \\ Linfield College
}

\begin{abstract}
Shibusawa Eiichi (1840-1931) has been called the "father of Japanese capitalism" and was associated with nearly five hundred business enterprises in his lifetime. From his main position as head of Dai Ichi Bank, Shibusawa was a strong advocate for business interests when the Japanese government was generally preoccupied with military concerns. He also consistently argued that business leaders should look to Confucian principle for moral guidance if they were to maintain the public's trust. Through an analysis of Shibusawa's public statements and his legacy in subsequent historical scholarship, particularly Dai Ichi Bank's 1957 official company history, we see that appeals for strong civilian initiative guided by both moral principle and economic rationality have long been an important theme in modern Japanese economic and business history.
\end{abstract}

\section{Introduction}

Shibusawa Eiichi (1840-1931) is today remembered as one of the principle architects of the modern Japanese economy. Associated with nearly 500 business enterprises, he has even been called the "father of Japanese capitalism." As a young man helping with his father's farming and sideline indigo business, Shibusawa became disillusioned with the Tokugawa era status system which elevated samurai officials over farmers and merchants by birthright rather than ability. Rising quickly in the political turbulence preceding the Meiji Restoration and traveling to Europe in 1867, Shibusawa became further convinced of the need to mobilize people of all social classes to build Japan's national prosperity and strength. Shibusawa served in the Meiji government's ministry of finance from 1869, but left government and became the head of the First National Bank (Dai Ichi Kokuritsu Ginkō) in 1873. From this position, he helped create modern economic institutions like banks, insurance companies, and stock exchanges and invested in railroads, textile mills, shipping companies, and other industries.

The Meiji Japanese government was committed to developing modern industries and military power. This commitment was enshrined in the famous slogan "Rich Country, Strong Army" (fukoku kyōhei), which suggested a consensus around the goals of economic growth and military prowess. These two goals, however, could be competing as well as complementary. When military budgets eclipsed other considerations, Shibusawa lobbied government leaders to place a higher priority on private sector investment. He also called on business leaders to consider carefully the moral implications of their actions and become worthy of the public's trust and support. 
In his speeches and writings, Shibusawa promoted the joint-stock corporation as a better mechanism, than government initiatives, for pooling people's talents and ambitions in service of the national interest. To counter the common view that private enterprise was selfish, he also argued for the "unity of morality and economy" to create a positive image of the modern Japanese business leader.

Through an analysis of Shibusawa Eiichi's public statements and his portrayal as company founder in the 1957 official company history Dai Ichi Ginkō Shi, we will see how he crafted and tirelessly promoted the attractive message that, if enterprises were conducted in the name of the national interest, one need not sacrifice ethical principles in the pursuit of private wealth. By equating entrepreneurship and national service, Shibusawa facilitated Japanese society's acceptance of capitalist economic organizations.

\section{Revere Officials and Despise the People}

Born the eldest son of a wealthy farm family near present-day Tokyo, Shibusawa Eiichi was given a thorough education in the Confucian classics. Like many prosperous farmers in the late Tokugawa era, Shibusawa's father Yoshimasa managed not only his family's farm, but also a side business processing indigo, which he would buy from other farmers to produce dye for sale to weavers of fabric. Shibusawa worked with his father and helped negotiate terms with indigo growers and weavers. Sometimes he would meet with samurai officials along the way and Shibusawa would later recall hating their attitude of "revere officials and despise the people" or kanson minpi. In his autobiography, Shibusawa recalled, "it occurred to me that the Tokugawa system of government was not good. In my view, it was only right that a person have full possession of his property and be judged on the basis of his intelligence and ability in dealing with his fellowmen." "Throughout his life, Shibusawa consistently argued that the kanson minpi attitude, which conferred unearned status on government officials, promoted government abuse of power while stifling private initiative.

In the 1860s, young militants were attacking foreign settlements and Japanese government officials responsible for allowing foreigners to reside in Japan. Shibusawa left home to participate in a planned attack on foreign merchants in Yokohama, but soon abandoned the plot. Instead, he traveled to Kyoto, which was a center of revolutionary discontent. Impressing the right people with his ambition and knowledge of accounting, Shibusawa was granted samurai status and became a retainer of the last Shogun Tokugawa Yoshinobu.

Accompanying the shogun's younger brother, Tokugawa Akitake, to the 1867 Paris Exposition and studying modern economics for nearly a year in Europe, Shibusawa was further convinced that Japanese attitudes toward commerce needed to change if the country was to become wealthy and strong. He was particularly struck by the high status that merchants and industrial leaders enjoyed in European societies, a sharp contrast to the disdain that Tokugawa samurai officials had for merchants in Japan. As Shibusawa noted, "For officials and the people to become of one accord to enrich the nation, the custom of revering officials and despising the people must be destroyed. This must be done to bring about a new era."2

When the shogun was overthrown and the Emperor Meiji's authority was restored in 1868, Shibusawa joined the new government's Ministry of Finance and helped reform the land tax and banking systems. In the early 1870 s, he left government in a factional dispute, but became the first president of the Dai Ichi Kokuritsu Ginkö (First National Bank) through his connections with the Mitsui and Ono merchant financial groups. ${ }^{3}$

In Dai Ichi Bank's official company history, Dai Ichi Ginkō Shi, published in 1957, Shibusawa's role as founder occupies a defining position in the narrative. In the section entitled "Dai Ichi Kokuritsu Ginkō's Role in Financial History," the company history argued that the bank's major significance could be understood in five areas: 1) establishing the currency system as a national bank; 2) taking deposits and making loans to establish modern banking; 3) cooperating with the government on its "Promote Production and Encourage Enterprise" (shokusan

${ }^{1}$ Eiichi Shibusawa, Autobiography of Shibusawa Eiichi: From Peasant to Entrepreneur, trans. Teruko Craig (Tokyo: Tokyo University Press, 1994), 13.

${ }^{2}$ Shibusawa quoted in Jun Inoue, Shibusawa Eiichi: Kindai Nihon Shakai No Sōzōsha, (Tokyo: Yamakawa shuppansha, 2012 ), 34.

${ }^{3}$ Dai Ichi Ginkō hachijūnen shi hensan shitsu, Dai Ichi Ginkō Shi (Tokyo: Daichi Ichi Ginkō, 1957), 56-57. 
$k \bar{o} g y \bar{o})$ policy spreading savings and loan practices first to Japan and then Korea; 4) as a "corporate enterprise" (gappon kigyō), Dai Ichi helped develop the corporate model for Japanese business and 5) as a conduit for Chairman Shibusawa Eiichi's moral vision of "Uniting Virtue and Economy" (dotoku keizai gōitsu). The Dai Ichi Ginkō Shi summarized Shibusawa's experience as follows:

When Chairman Shibusawa returned from Europe in the first year of Meiji, he was strongly convinced from his experience in the West in the importance of promoting cooperative capitalism (gapponshīgi) and abolishing the attitude of revering officials and despising the people (kanson minpi). In January 1869 as an official in the Shizuoka domain, he promoted cooperative capitalism by founding the Commercial Office (Shōhō Kaijo). In 1871, as an official in the Ministry of Finance, he called for cooperative capitalism (gapponshügi) and democracy (minshüshügi) in the pamphlet "Rikkai Ryakuzoku". In November 1872, the National Bank Plan was made public and he took a major role in implementing his vision of promoting the corporate enterprise. ${ }^{4}$

The Dai Ichi Ginkō Shi then focused on the plight of the precursors to the national banks as an object lesson on the failure of government intervention in corporate affairs. After the Meiji Restoration, financial institutions were reorganized as "exchange companies" (kawase kaisha) in the port cities to handle commercial transactions. Making the case for Dai Ichi as the first modern corporation in Japan, The Dai Ichi Ginkō Shi noted that these exchange companies an "incomplete" corporate form. They had private shareholders but were controlled by government officials and shareholder liability was not limited as in the case of the modern joint-stock company. The historical narrative then blamed the failure of the exchange companies on the "mixing of government and civilian" (kanmin konkō). ${ }^{5}$ In this account, an ambiguous relationship between government officials and private investors was considered a serious problem and the independent joint-stock company was an important contributor to Japan's subsequent economic growth.

Shibusawa's notion of gapponshīgi capitalism was a marked contrast to both the Tokugawa-era merchant house and the zaibatsu family-owned industrial conglomerates that became major forces in the Meiji Japanese economy. The merchant houses and zaibatsu conglomerates represented a closed system of ownership and governance where enterprises were managed to maximize the fortunes and survival of individual families. Gapponsh $\bar{u} g i$ capitalism, on the other hand, insisted on open joint ownership among multiple shareholders and the democratic election of a competent board of directors. Shibusawa believed that a properly elected board of directors, like representatives in a republican form of government, would be more likely than an autocratic company president to make rational business decisions compatible with both public and private interests. As Shibusawa said, "If only one person becomes wealthy, the country does not prosper. The country must become strong. Especially now when the position of merchants and industrialists is so despised, there is no other way to think than to remember that we want to save the nation from its weakness and work for the prosperity of the whole."

To further promote his vision of gapponshügi capitalism, Shibusawa helped found the Tokyo Chamber of Commerce in 1878. Later he recalled his motivation for joining the organization:

I founded Dai Ichi Bank wanting to promote business and the joint-stock company structure to compete with the civilized countries, but even with a bank, there must be a field in which to work. We had to build our skills. I intensely felt the need to show how enterprises built on the joint-stock model could improve the productivity of all industries and poured all my efforts into explaining it to those who wanted to hold onto the old ways. ${ }^{7}$

The Tokyo Chamber of Commerce became an important vehicle for Shibusawa to develop business activity and the ideas that supported it. Working out the precise relationship between civilian investors and government officials would prove a lifelong endeavor.

${ }^{4}$ Ibid, 3-4.

${ }^{5}$ Ibid, $54-55$

${ }^{6}$ Masakazu Shimada, "Shibusawa Eiichi Ni Yoru Gapponshūgi," in Gurobaru Shihonshūgi No Naka No Shibusawa Eiichi, ed. Patrick Friedenson and Takeo Kikkawa, 1-34 (Tokgyo: Toyo keizai shinpōsha, 2014), 10-11.

${ }^{7}$ Shibusawa quoted in Teiji Kenjō. Shibusawa Eiichi: Dōtoku to Keizai No Aida. Hyōden - Nihon Keizai Shiso. (Tokyo: Nihon keizai shinbunsha, 2008), 49 
Japanese Economic and Military Expansion in East Asia

Shibusawa Eiichi and the Dai Ichi Bank actively supported Japanese economic and military expansion in East Asia. Dai Ichi was the first Japanese bank to open an overseas office in Pusan in $1878 .{ }^{8}$ It later became the acting central bank in Korea and issuer of Korean currency until it was replaced by the colonial Bank of Korea.

In the Dai Ichi Ginkō Shi, we see that Shibusawa played a major role in the bank's expansion into China and Korea. In 1876, Shibusawa discussed loans to the Qing governments financed partly with samurai bonds and partly with government funds. Dai Ichi also had a special role with Korea handling customs receipts and issuing bank notes through an agreement with the Korean king. ${ }^{9}$

In 1890, Shibusawa addressed the general meeting of his "Dragon Gate Society" study group. In this speech, entitled the "State of our Country's Industry," he reiterated earlier Meiji economic nationalist themes that the strength of the country rested on the prosperity of its economy and that Japanese industry should seek to replace foreign imports with domestic products. However, he argued that private enterprise had the responsibility for developing Japan's economy. To overcome Japan's capital scarcity and high interest rates, investors would have to coordinate their efforts to develop joint-stock companies. ${ }^{10}$

In 1893, Shibusawa served on the Currency System Investigation Committee, which Finance Minister Matsukata Masayoshi convened. Shibusawa opposed Matsukata's plan to move Japan to the gold standard because he believed it would require issuing foreign bonds and the cost would have a negative effect on Japan's business climate. $^{11}$ In his published opinion, Shibusawa again used the economic nationalist argument that policy should be made on the basis of benefits rather than economic theory. "Currency is only a standard of value and medium of exchange for transactions. Therefore, we should not ask whether it should absolutely be gold or silver. When looking at the pros and cons of each [currency option], it is important to survey the country's economy and evaluate the good and bad to see if changes are necessary."12 He saw silver as clearly advantageous when he stated, "Looking at our international trade in recent years, changes in the relative prices of gold and silver has had the tendency to benefit our exports to gold currency nations." 13 With silver depreciating relative to gold, Japanese exporters benefited from their goods becoming increasingly competitive in countries with gold-backed currency.

During the First Sino-Japanese War of 1894-1895, Shibusawa supported the war effort by forming the "Inform the Nation Society" or Hōkokukai with Fukuzawa Yukichi, Mitsui Hachirōzaemon, and Iwasaki Hisaya to sell war bonds and solicit contributions. Shibusawa himself contributed 1000 yen and another 190 yen to help families of veterans. He also bought 300,000 yen in bonds and Dai Ichi bought 700,000 yen. These efforts earned Shibusawa a letter of gratitude from Finance Minister Watanabe Kunitake. ${ }^{4}$ From these actions, we can see that Shibusawa Eiichi did not necessarily oppose Japanese economic expansion in Asia, nor Japan's wars of territorial acquisition on moral grounds.

However, Shibusawa did disagree with government officials on economic policy questions raised by the large indemnity that the Qing government in China was forced to pay Japan. Shimada Masakazu has noted that after the Sino-Japanese War, Shibusawa was fairly assertive in making his case against the government's economic policies to the public. In newspapers and magazines, he frequently criticized the government's use of the indemnity acquired from China, plans for the gold standard, accumulation of foreign debt, and plans to nationalize Japan's railroads. Shibusawa hoped that the government would use the indemnity to fund infrastructure development over

\footnotetext{
${ }^{8}$ Mark Metzler, Lever of Empire: The International Gold Standard and the Crisis of Liberalism in Prewar Japan. (Berkeley: University of California Press, 2006), 40-41.

${ }^{9}$ Dai Ichi Ginkō Shi, 408-415.

${ }^{10}$ Shibusawa Eiichi. "Shibusawa Eiichi No Ensetsu 'Honpo Kōgyō No Genjo'.” in Keizai Kōsō, 325-333, (Tokyo: Iwanami shoten, 1988), 326329

${ }^{11}$ Kenjō, Shibusawa Eiichi: Dōtoku to Keizai no Aida, 80-82.

${ }^{12}$ Shibusawa Seien Kinen Zaidan Ryūmonsha, Shibusawa Eiichi Denki Shiryō (Tokyo: Shibusawa Eiichi denki shiryō kankokai, 1955-1971), 23: 175.

${ }^{13}$ Ibid, 177.

${ }^{14}$ Kenjō, Shibusawa Eiichi: Dōtoku to Keizai no Aida, 76-77.
} 
military expansion. ${ }^{15}$

In an article entitled "A Discussion of the Postwar Economy," which appeared in Yomiuri Shinbun in late August 1895, Shibusawa criticized plans for further military buildup.

As military leaders, from their perspective, hope for larger budgets to support rapid expansion of naval and land forces, business leaders, from their own perspectives, hope that expansion of military budgets will be small and those resources directed toward more productive uses. I do not know to what extent the government seeks to expand the military this time, but I am unable to support the projected expansion of army troops by several hundred thousand and naval personnel by several hundred thousand even with the three-country alliance. Even if this is a one-time expansion that can be easily accomplished using the indemnity, it will greatly increase the level of military spending required to support that many troops as well as administration costs year in and year out. ${ }^{16}$

Shibusawa Eiichi was concerned that the use of the indemnity acquired from China for a temporary expansion of military spending would lead to a long-term economic burden. He argued that rather than increasing military budgets, the indemnity should be channeled toward productive investments, industrial promotion, and retiring war bonds to reduce government debt. ${ }^{17}$

Shibusawa believed that there needed to be a balance between military needs and the expansion of commerce and industry. If military budgets expanded too rapidly, it would place a heavy burden on the rest of the economy. He spoke out against large military budgets when the corporate tax law was reformed in 1896 arguing that commerce and industry was the very foundation of European power. When land tax was reformed in 1897, he also argued that tax laws must consider first the vitality of agriculture, commerce, and industry while at the same time addressing military concerns. ${ }^{18}$

The cost of the government's military expansion was indeed enormous. Between 1897 and 1901, the planned increases in military spending were 101.6 million yen for the Army plus 211.7 million yen for the Navy making the total increase 313.3 million yen. This increase was to be financed with 196.1 million yen from the Chinese indemnity, 39.7 million yen from tax revenue and 77.5 million yen by issuing bonds. The government also had other projects in addition to military expansion: Building and improving railroads, expanding telephone service, water works, developing Hokkaido, encouraging shipping, and managing Taiwan all contributed to rapid government budget growth. To pay for it, the government planned to revise corporate tax and raise liquor and tobacco taxes. Shibusawa spoke against these plans at a Chamber of Commerce meeting at the Imperial Hotel in November $1896 .^{19}$

In 1898, the government's budget included additional funding for expansion of shipping and increasing funds to manage Taiwan, which exceeded receipts by 21,000,000 yen. Once again, corporate taxes, land tax, as well as sake and tobacco taxes would have to be raised. Shibusawa spoke to an alliance against military expansion at the Imperial Hotel in December $1898 .^{20}$

In addition to military budgets, the decision to move Japan to the gold standard was also a pressing issue immediately following the First Sino-Japanese War. Japanese government leaders like Matsukata Masayoshi favored the gold standard because they believed that it represented civilization and would contribute to Japan's status as a modern "first-rate" country. After the Sino-Japanese War, it was clear that military expansion would require loans from European financial markets, which operated in gold. Matsukata and his supporters also believed that

\footnotetext{
${ }^{15}$ Shimada, Masakazu. Shibusawa Eiichi no kigyōsha katsudōno kenkyū: senzenki kigyō shisutemu no sōshutsu to shusshisha keieisha no yakuwari. (Tokyo: Nihon Keizai Hyōronsha, 2007), 342-343.

${ }^{16}$ Shibusawa Eiichi Denki Shiryō, bekkan 6: 268.

${ }^{17}$ Masakazu Shimada, "Nisshin Sengoki No Keizaikan: Keizai Seisaku E No Iken to Kōdō," in Kōeki no Tsuikyūsha - Shibusawa Eiichi, ed. Shibusawa kenkyūkai (Tokyo: Yamakawa shuppansha, 1999), 60-73., 63.

${ }^{18}$ Kenjō, Shibusawa Eiichi: Dōtoku to Keizai no Aida, 79-80.

${ }^{19}$ Takao Tsuchiya, Shibusawa Eiichi (Tokyo: Yoshikawa kōbunkan, 1989), 226-227.

${ }^{20}$ Ibid, 228-230.
} 
moving Japan to the gold standard would help establish Tokyo as a major financial center in East Asia. ${ }^{21}$

In February 1898, Shibusawa was interviewed in the financial journal Chūgai Shōgyō Shinpō on the issue of currency reform. When asked if he opposed the government proposal because it was not in Japan's interest, he replied:

The Bank of Japan's level of specie preparation is currently lacking. Although the Bank's reserves are expected to increase with the indemnity and may be adequate, much of the indemnity has already been earmarked for other government expenses and much of it will flow overseas as unexpected costs. If this eventuality is not considered in the government's calculations, the necessary specie reserves will be inadequate. This inadequate preparation is my first concern about the proposed currency reform. The proposal is also based on an optimistic assessment of the future of international trade. If future exports exceed imports, the result will be specie flowing into our country and will have a tendency to increase currency reserves replenishing what is lacking. However, we do not know if they will increase tariffs or if falling silver prices may not be trivial. Last year our overseas trade was affected by a slump in American commerce and an increase in demand for imports after winning the war, but on the other hand, don't imports usually greatly exceed exports? We just have to look at India after that country's currency reform. Imports regularly exceeded exports and caused great difficulty. Therefore, we need to know whether our trade, that is, whether our imports will increasingly exceed exports, and whether the expected currency inflow is not just a hope. The calculations of how currency flows in the future will affect our currency reserves is my second concern. ${ }^{22}$

Once again, Shibusawa urged the government to carefully consider future consequences. Although there might have been political reasons to join the international gold standard to align Japan more closely with European powers, any potential economic benefits depended heavily on Japan's future trade balance. Shibusawa believed Japan's current gold and silver reserves to be insufficient and he argued that it was dangerous to base such an important policy change on overly optimistic projections of future currency flows.

In these public statements from around the time of the First Sino-Japanese War, we can see that Shibusawa Eiichi advocated a gradualist approach to imperialism that carefully weighed the costs of government policies. After 1895, the two goals of Meiji economic development, "rich country" and "strong army" were in tension as military budgets consumed an ever-greater portion of the nation's resources. Unfortunately, "strong army" won out as the Japanese government became obsessed with developing military might and international prestige at any cost.

\section{Changing Concerns after the Russo-Japanese War}

The Russo-Japanese War was an important turning point for both the Japanese economy and Shibusawa's outlook. Business and political leaders during the Meiji era had pursued economic development in the name of national security. The Anglo-Japanese Alliance of 1902 and the 1905 victory over Russia transformed Japan's role in East Asia. Rather than simply defending its own national sovereignty, Japan was now in a position to compete with the Western powers for empire. As a business leader, Shibusawa supported Japanese foreign policy, which he believed would open new markets to Japanese goods and minimize foreign threats. But, he was worried that the Japanese state was expanding too aggressively and that the civilian economy was suffering neglect.

In the January 1905 issue of Jitsugyō no Nihon, Shibusawa argued that not only were political reforms and cultural achievements important, but the countryside's increases in the productive capacity and wealth should also be recognized. "Wealth is a major strength for both the individual and the nation." Shibusawa wanted people to understand that wealth was a key component to the ability to advance civilization. He also pointed out that, throughout his career, he had labored to raise the status of business and demonstrate how people might pool their resources and use the joint-stock system of corporate ownership as an engine of progress. ${ }^{23}$

\footnotetext{
${ }^{21}$ Steven Bryan, The Gold Standard at the Turn of the Twentieth Century: Rising Powers, Global Money, and the Age of Empire (New York: Columbia University Press, 2010), 154-157.

${ }^{22}$ Shibusawa Eiichi Denki Shiryō, 23: 649.

${ }^{23}$ Shibusawa Eiichi Denki Shiryō, bekkan 6: 312-324.
} 
In the same article, Shibusawa observed that in the wars with China and Russia, soldiers and sailors had distinguished themselves in their commitment to the ideals of "The Way of the Warrior" or bushido. He said, "Now when the empire battles the world's strongest countries, victory is not only a function of military power. There is also a war in business and we must struggle to win in the world's markets. As our soldiers establish a foundation of loyalty to topple a strong enemy, so the young fighters of the business world must build a business spirit on the foundation of commercial ethics based on sincerity." 24 By comparing business competition to Japan's recent military victories, Shibusawa appropriated the martial virtues of resourcefulness and loyalty and depicted those engaged in business on a mission of service to the nation.

Despite his use of military imagery, Shibusawa did not fully accept the government's imperial agenda. In November 1907, Shibusawa was critical of the government's economic policies and said that if the burden of public finance was too heavy, it would restrict economic growth. If government expenditures consumed all of the nation's capital, it would not be available for enterprises. He further stated that the Sino-Japanese War had greatly increased government spending and the Russo-Japanese War accelerated this trend. Shibusawa then warned that the Japanese government's relatively high per capita expenditures were not sustainable. ${ }^{25}$ After the Russo-Japanese War, therefore, Shibusawa increasingly viewed civilian and government sectors as competitors for national economic resources and social prestige.

Shibusawa recognized that, with the acquisition of empire, business leaders needed to resist the drive of government and military officials for increased control of Japan's economy. In a March 1908 article in Taiyō, Shibusawa argued against viewing loyalty to the nation in strictly military terms. He applauded the bravery of soldiers and celebrated their accomplishments, but he also said that Japan had many domestic problems requiring attention. "At times of war, we are willing to give everything for the country, and military expenses expand accordingly. However, now militarism has become the source of financial difficulties. During the war, we needed to raise money abroad through bonds and now we must repay them. Military and government leaders are asking the people to bear enormous sacrifices and we must question whether the benefits justify those sacrifices."26

In the same article, Shibusawa criticized the recent government move to nationalize Japan's railroads. Civilian firms, he said, should be left to civilian managers who must continually improve their products and services to remain competitive. Government operation of the railroads, he feared, would serve military rather than civilian transportation needs. As he said, "We certainly need an economically oriented nationalization rather than a military oriented nationalization." If the railroads were operated according to civilian economic needs, Shibusawa argued, railroad service would expand and encourage the production of other goods. Instead, he noted, that larger government budgets meant higher taxes. As he said, "The people are not weak, but the burdens of a great power are heavy. The cost of the Russo-Japanese War was high for the Japanese economy. We need to turn our attention away from military spending to build up the economy." ${ }^{27}$

Shibusawa also opposed government intervention in labor markets. In March 1908, Shibusawa discussed in Osaka Shinpō his views of a potential labor law and other social problems. He admitted that some get wealthy in commerce and industry and that the wealthy have a different point of view than those who labor. Scholars were concerned that the conflict between capital and labor would become as severe as they observed in Western countries. Shibusawa noted that a group of scholars in the Social Policy Group were investigating Japan's growing social problems and advocated laws to protect workers in the textile industry. Shibusawa opposed such legislation on the grounds that workers needed to work long hours to make as much money as possible. He also wondered how factory owners would find the funds to pay for healthcare. Rather than protecting workers with laws, Shibusawa argued that each enterprise should consider itself a family. If capital treated labor according to the Way of Sages and labor treated capital the same way, everyone would be better off. "When trying to address the problem of poverty," Shibusawa said," we must remember to work for the good of the country, because the nation's wealth and individual wealth are one and the same. Following the Way of Sages can help both high and low to prosper." ${ }^{28}$

By the time of Shibusawa's retirement in 1909, the Japanese government's role in the economy was

\footnotetext{
${ }^{24}$ Ibid, 312-324.

${ }^{25} \mathrm{Ibid}, 376-377$.

${ }^{26}$ Ibid, 387-392

${ }^{27}$ Ibid, $387-392$

${ }^{28}$ Ibid, 383-386
} 
growing. To resist this trend, Shibusawa had a strong incentive to go on the ideological offensive, which he did with many speeches and writings.

\section{The Ryūmonsha and the "Unity of Morality and Economy"}

After his retirement from Dai Ichi Bank and most of his formal positions on boards of directors, Shibusawa became more involved with the Ryūmonsha study group. The Ryūmonsha or Dragon's Gate Society was a study group which Shibusawa's followers had formed in 1885 to discuss the adaptation of Western business practices to the Japanese economy. It drew its name from the Chinese story of a small carp swimming upstream which managed to jump the treacherous rapids at the Dragon's Gate and was transformed into a mighty dragon. In 1907, Shibusawa explicitly described the group's mission as promoting Confucian ethical principles in business practice and from 1909 , the group sponsored speeches and scholarly meetings to carry this message to the wider public. ${ }^{29}$

Shibusawa often spoke of his belief in the possibility and desirability of achieving the "unity of morality and economy." His most famous book the Analects and the Abacus was published in 1916 to promote the application of Confucian principles in business affairs. In one section of this work entitled, "The Way of the Warrior and Business," Shibusawa argued that the merchant and artisan classes of the Tokugawa era had fundamentally misunderstood Confucian principles, thinking they only applied to the samurai warrior class. Moreover, Confucian scholars of the past were similarly mistaken in thinking that commercial activity was incompatible with social morality. To prove his point, Shibusawa wrote, "Position and wealth are what the sages and wise men hoped for, while no one hoped for poverty and want." ${ }^{30}$ Later, he argued that Western countries were civilized because they had a high regard for commerce and that public morality was higher because people in the West were concerned with profit. "[The merchants of these countries] respect agreements between themselves because there is profit and loss involved and once a promise is made, they certainly follow through and do not break it." ${ }^{31}$ He contrasted his idea of Western honesty and fair-dealing with his view of Japan's traditional merchant class, which he believed would do anything for a momentary advantage.

To improve Japanese business ethics, Shibusawa called for an awakening of Way of the Warrior saying that "Japanese people will always have Bushido born of the Yamato spirit living which must rise in the world. Whether it is in commerce or industry, if we embrace this in our hearts, Japan will battle for position in the world as it has in fighting wars." ${ }^{32}$ By deploying the symbols of Japan's samurai past, Shibusawa was demonstrating to the Japanese public that those following careers in business could be just as devoted to national welfare as those engaged in military service.

In 1916, Shibusawa said, "The characteristic of the current state of Japan that is most deplorable is the poisonous notion of "revere officials and despise the people" that still must be stopped... When the people contribute to advance the nation, their efforts go unrecognized, but praise is lavished on officials for small deeds." ${ }^{\text {, Nearly }}$ fifty years after the Meiji Restoration, the respect that government and military officials commanded in Japanese society was still high. To compete, business leaders like Shibusawa had to constantly publicize the virtues of civilian commercial activity.

From 1923 to 1925, Shibusawa gave a series of lectures on the Analects of Confucius, which became another key source in understanding his views on morality and economy. Going through the Analects line by line, he gave his interpretations of Confucius' thought and illustrated their application using examples from Japanese history and his own life. In his commentary on Confucian views of learning, Shibusawa said, "Learning is not for oneself. Cultivate character and then act. Real learning is applied learning. From 1873, when I was thrust into the business world, until now, I have worked on harmonizing morality and economy. The application of the Sage's teachings is the foundation for these efforts. There are many today who can speak beautifully, but lack the courage to act on

\footnotetext{
${ }^{29}$ Kenjō, Shibusawa Eiichi: Dōtoku to Keizai No Aida, Hyōden, 135-136.

${ }^{30}$ Eiichi Shibusawa and Atsushi Moriya, Gendai Yaku Rongo to Soroban (Tokyo: Chikuma shobo, 2010$), 167$.

${ }^{31}$ Ibid, 168.

${ }^{32}$ Ibid, 169

${ }^{33}$ Shibusawa Eiichi Denki Shiryō, bekkan 7: 27-28.
} 
these principles and apply them to management." ${ }^{34}$ By downplaying profit and emphasizing loyalty to family, friends, and nation, Shibusawa portrayed business as a noble calling if pursued for the right reasons.

The importance of morality was the consistent theme that he drew from Confucius as he encouraged his audience to consider the greater good when conducting their professional lives. Confucius said, "The noble person knows about integrity. The petty person knows about profit." Shibusawa interpreted this to mean that the person of noble character considers the benefit of all while petty people think only of themselves. He then gave the example for his own experience of using his position as head of Dai Ichi Bank to facilitate the sale of railway bonds because he believed railways were important to the nation's future. When the railways were nationalized many people made a lot of money speculating on price fluctuations, but Shibusawa said he refrained from doing so because he believed the short run profit came at the expense of long-term trust and reputation. ${ }^{35}$

Shibusawa consistently argued that moral principle had indeed guided his own business activities at all times. When considering enterprises, he said he did not really consider profit. Rather he thought to himself, "This enterprise is essential" "Or this enterprise must succeed." "When thinking of enterprises, I never considered whether it would profit me personally, but rather thought of whether it advanced everyone's interests." ${ }^{36}$

Japan in the 1920s was caught in a prolonged post-World War I recession, which was inviting increased extremism from both the left and right wings. With Japanese political democracy and economic liberalism, Shibusawa Eiichi's appeals to Confucian virtue can be seen as a third path between modern liberal individualism and fanatical devotion to the state. The key issues of Shibusawa's sunset years were the proper roles of labor and capital, the extent to which democratic government was appropriate to Japan's circumstances, and the extent to which Japan should cooperate in the imperialist world order. About the time of Shibusawa's death in 1931, Japanese democracy collapsed with the onset of the Great Depression and the Japanese military launched a new phase of aggressive imperial expansion on the Asian mainland.

In 1952, the Dai Ichi Bank celebrated its eightieth year in business. Five years later, the bank published the Dai Ichi Ginkō Shi in two volumes. With the Allied Occupation ended, the bank was looking forward to new economic opportunities. Perhaps seeking to renew the company's corporate identity and sense of mission, the Dai Ichi Ginko Shi focused particularly on the story of its founding Chairman Shibusawa Eiichi and the ethical values that he promoted throughout his lifetime.

The effectiveness of the Shibusawa story is still apparent today in Japan's historical and popular literature. When explaining this enduring positive image in his biography of Shibusawa, Tsuchiya Takao wrote, "This is perhaps because Shibusawa was not simply an entrepreneur, capitalist, or wealthy person. Or perhaps it is because he was not someone who worked only seeking personal profit or to accumulate capital. At his core, Shibusawa was a great leader of the economic private sector who, from the Restoration promoted the good of Japanese society and modernization." ${ }^{37}$ In 2007, Lawson convenience store President and CEO Niinami Takeshi stated in that company's annual report, "The entrepreneur Eiichi Shibusawa, who is known as the 'father of Japanese capitalism,' summed this up effectively...As he said, I think that management which skillfully balances a Japanese-style corporate culture with global economic rationalism is the source of stable, long-term growth." ${ }^{38}$

\section{Conclusion}

In conclusion, we can see that the competing visions of government and business leaders for Japan's future created an environment in which Shibusawa Eiichi felt the need to speak out regularly to defend business interests. To defend civilian business interests in public discourse, Shibusawa regularly argued his case from an ethical and nationalist perspective. While this rhetorical strategy was necessary throughout the Meiji period, it was especially important after the Russo-Japanese War, when the military's share of national budgets and attention grew rapidly.

\footnotetext{
${ }^{34}$ Eiichi Shibusawa and Atsushi Moriya, Shibusawa Eiichi No Rongo Kōgi (Tokyo: Heibonsha, 2010$), 30$.

${ }^{35}$ Ibid, 84.

${ }^{36}$ Ibid, 85 .

${ }^{37}$ Tsuchiya, Shibusawa Eiichi, 270.

${ }^{38}$ Lawson, Inc., Annual Report 2007 (Tokyo: Lawson, Inc., 2007), http://www.lawson.co.jp/, 9.
} 
After the Second World War, Shibusawa Eiichi continued to be an inspiring symbol for business leaders seeking to maintain their independence from government interference while at the same time following a set of ethical principles that promote both public and private interests. Promoting modern business enterprises as a means for acting on earlier ethical values, Shibusawa Eiichi's enduring contribution was to sell capitalism itself as a positive force in Japanese society.

\section{$(\mathrm{cc}) \mathrm{Br}$}

New articles in this journal are licensed under a Creative Commons Attribution 3.0 United States License.

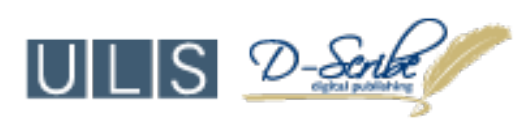

This journal is published by the University Library System, University of Pittsburgh as part of its D-Scribe Digital Publishing Program and is cosponsored by the University of Pittsburgh Press. 